\title{
An outline of Parks Victoria's Tourism Partnerships Strategy and challenges for sustainable park tourism in Australia
}

\author{
M. Stone \& D. Smith \\ Parks Victoria, Australia
}

\begin{abstract}
Throughout the world there is growing recognition of the vital contribution parks make to a healthy environment, to the health of individuals and to a healthy society. The natural environment and wildlife are also key elements of Australia's global tourism appeal and are attributes that differentiate Australia from competing tourism destinations.

Within Australia, the state of Victoria is fortunate to have inherited a world-class network of parks and reserves, now accounting for more than $17 \%$ of the state. Parks Victoria is responsible for managing these national and state parks, marine national parks and sanctuaries, regional and major metropolitan parks and conservation reserves. These include many of the iconic locations on which Victoria is marketed, such as Port Campbell (the 12 Apostles), the Grampians and Wilsons Promontory National Parks. Parks Victoria receives over 70 million visits a year, making it one of the biggest tourism providers in Australia.

Parks Victoria's overall role is to protect the natural and cultural values of the parks and other assets it manages, while providing a range of outdoor opportunities for all visitors. Its specific role in tourism is to work in partnership with industry, government and the community to facilitate appropriate and sustainable tourism on and for public land.

During the past three years, Parks Victoria has worked closely with the tourism industry in recovering from significant regional bushfires. Innovative solutions have been developed to enable ongoing park tourism and address the challenges facing sustainable park tourism state-wide. This paper outlines these initiatives including the balance of protection and promotion, creation and maintenance of appropriate visitor facilities and services, recognition of the value of parks, and effective partnerships.

Keywords: sustainable tourism, national parks, strategy, visitor facilities and services, healthy environment and society, bushfires, protection and promotions, partnerships.
\end{abstract}




\section{Introduction}

Parks Victoria (PV) has a key role in the provision of nature based tourism products and services as well as a core responsibility to manage and protect the park estate for future visitors and Victorians. PV has developed a Tourism Partnerships Strategy to inform and provide clear guidelines about tourism and parks, set future directions for PV's role in tourism and outline how it can facilitate appropriate and sustainable tourism opportunities on and for the areas it manages.

Five elements of the Strategy are outlined in this paper as well as the four main challenges facing sustainable nature based tourism in Victoria, including the recovery from natural disasters, such as bushfires.

\section{Background}

\subsection{Tourism structure and parks}

Tourism contributes more than AUD10.5 billion to Victoria's economy, generates 175,000 jobs, and delivers opportunities in many regional locations.

Parks contribute significantly to Victoria's reputation as both a place to live and a place to visit. In Victoria's Tourism Industry Strategic Plan 2002 - 2006, nature based tourism was identified as tourism product strength for Victoria [1]. In 2005, there were 44 million visitor nights attributable to nature based tourism recorded in Victoria [2]. Australia's natural areas influence $56 \%$ of international visitors to visit Australia [3].

Protected areas such as national parks play an integral role in nature based tourism. This role is twofold - first, protected area landscapes and infrastructure provide the essential base for many nature based tourism activities. Secondly, protected areas provide the setting or backdrop for many tourism opportunities that may not physically occur within the area but which draw on the parks' natural features, such as off park accommodation. Parks Victoria also operates many tourism businesses (directly or through commercial partners) and is actively developing new park tourism products.

National Parks in Victoria are major drawcards for tourists to visit regional areas. Parks such as Mornington Peninsula, Port Campbell, Grampians and Dandenong Ranges each receive more than one million visits a year. Other parks such as Wilsons Promontory, Mt Buffalo and Croajingolong provide icon images for tourism.

\subsection{What Parks Victoria manages}

Parks Victoria was established in 1996 and is a statutory authority that reports to the Minister for Environment. Parks Victoria manages $17 \%$ of the area of Victoria, including many of the iconic locations on which Victoria is marketed, such as the 12 Apostles (Port Campbell), the Grampians and Wilsons Promontory National Parks. There are over 70 million visits to the parks estate a year. 
PV manages state, reservoir, and metropolitan parks, marine parks and rivers, heritage sites and locations that play a significant role in attracting visitors to Victoria. These include Albert Park, Castlemaine Diggings National Heritage Park (the first National Heritage Park in Australia), Tower Hill Reserve, Walhalla Historic Area, Yarra River, and Port Phillip Bay.

PV operates major tourist attractions and products (fee for entry) including William Ricketts Sanctuary, Werribee Mansion, Great Gardens of the Dandenongs, Buchan Caves, and the Yarra River Shuttle Service.

PV plays a major role in the delivery of major state tourism projects and works with partners and lessees in the management of tourism venues. These include: Queenscliff Harbour, Mount Buffalo Chalet, 12 Apostles Visitor Centre, Mt. Dandenong Observatory, Brambuk the National Park and Cultural Centre, St. Kilda Kiosk and lightstations.

\subsection{Current situation}

Appropriately managing the existing range of park facilities and settings is essential to Victoria's tourism reputation, as is working with the tourism industry to develop and deliver enhanced sustainable park tourism products and experiences. In relation to the latter, PV has a role in 'enabling' appropriate tourism development connected with public land. A combination of public and private sector assets and services can deliver outstanding park related tourism products and experiences.

Despite strong national park visitation (Figure 1), the perception of Victoria as a state with strong natural attractions by Australians is quite low. As highlighted in (Figure 2), the Roy Morgan Research 2005 Brand Health survey identifies Victoria as the second lowest state for brand recognition associated with 'world class natural attractions'. While Queensland (Great Barrier Reef Marine Park) and the Northern Territory (Uluru and Kakadu National Parks) are leading Australia in relation to 'world class natural attractions', their lead has decreased in 2005 .

\begin{tabular}{|c|c|c|c||c||c||c|c|}
\hline State/Territory & NT* & VIC & WA & NSW & QLD & TAS & SA \\
\hline $\begin{array}{c}\text { Visitation } \\
\text { (mil's) }\end{array}$ & 5.2 & 27.0 & 9.8 & 22.0 & 13.0 & 1.3 & 2.2 \\
\hline
\end{tabular}

Figure 1: Visitation to Australian protected areas parks (2001/02).

\subsection{Economic and social value of park tourism}

A study by one of Australia's leading accounting firms revealed that Wilsons Promontory National Park in south east Victoria had an annual contribution of AUD47 million to the regional economy. A similar study of the Grampians National Park in central west Victoria and Port Campbell National Park 
demonstrated an annual contribution of AUD246 million and AUD190 million to regional economies respectively [4]. In the context of these Victorian regions, parks are a significant part of the economy, and the important role parks play in Victoria's overall prosperity is reinforced. The role parks play in maintaining the social fabric of communities is also noted.



Figure 2: $\quad$ Roy Morgan Research 2005 Brand Health Survey.

A 1999 study using a travel cost methodology demonstrated a net contribution to the state economy from Victoria's parks of AUD960 million annually [5]. This does not include the value of environmental services provided by parks. (E.g. the provisions of clean water, carbon sequestration, clean air and biodiversity protection).

\section{Parks Victoria tourism strategy}

\subsection{Role in tourism}

Parks Victoria's role in tourism is to work in partnership with industry, government and the community to facilitate appropriate and sustainable tourism across the whole parks estate.

This is achieved by:

- $\quad$ protecting the recreation and tourism values of public land for the long term through sound policy, planning, management and governance,

- providing and maintaining appropriate visitor facilities and services on/for public land, and

- $\quad$ effectively communicating and promoting the role public land areas play in tourism.

\subsection{Definition of nature based tourism}

Nature based tourism is a segment of Park Tourism. In Victoria's Nature Based Tourism Strategy 2007-2011 (in progress), it is defined as any type of tourism that relies on attractions directly related to the natural environment [6]. 
Core nature based tourism activities include:

- Adventure Tourism - e.g. Climbing, Long distance hiking, Mountain Biking, Kayaking.

- Ecotourism - e.g. Aboriginal Tourism (in nature), Nature Observation, Whale Watching

- Core ethos - environmental and cultural education, appreciation, and conservation of natural areas.

- $\quad 3 S$ (Sea, Sun and Sand) Tourism - e.g. Boating, Sailing, Surfing and Beachcombing.

- $\quad$ Extractive - e.g. Fishing, Fossicking, Gold Panning.

- Native Wildlife Parks and Native Gardens.

- $\quad$ Nature retreats - e.g. Accommodation in nature.

Visiting a National Park is not defined as an activity in itself as various nature based tourism activities can take place within a National Park.

\subsection{How Parks Victoria manages tourism}

A summary of the five main Tourism Partnership strategies (in addition to the park management role) are outlined as follows.

\subsubsection{Planning, strategy and policy}

This includes policy, planning and implementation, monitoring and research, and development and support of appropriate tourism initiatives and products. PV provides strategic advice and input into many plans developed with, or by other agencies including Regional Tourism Development Plans, Victorian Trails Strategy, Tourism Plan for Melbourne's Waterfront, Victoria's Tourism Industry Strategic Plan and Victoria's Nature Based Tourism Strategy 2007-2011 (in progress). PV has developed tourism policy, tools and models and also provides information and direction to local government and regional tourism plans across the state.

\subsubsection{Conduit role}

PV plays an important role as a conduit between government and the tourism industry particularly for nature based and cultural tourism businesses operating on public land. PV works with a range of organisations to develop shared visions and achieve sustainable and appropriate tourism outcomes.

Key partner organisations include: Federal and state government tourism agencies, tourism associations such as Tourism Alliance and Victorian Tourism Industry Council, Department of Sustainability and Environment, Sustainable Tourism Cooperative Research Centre and local governments. PV is represented across the state on tourism boards, associations and committees ensuring appropriate positioning and messaging of the parks estate and the visitor experience.

The importance of these connections was paramount in dealing with recent bushfire events in Victoria. 


\subsubsection{Commercial operators}

In Victoria a tour operator licence system is administered by PV. The system is based on legislation requiring consent for an operator gaining commercial benefit from a public resource. When operators are licensed they must maintain appropriate Public Liability Insurance and operate in accordance with conditions.

There are over 260 Licensed Tour Operators providing over 3000 park based products. These include bushwalking, four wheel drive tours, horse riding, rafting, biking, ballooning, camping, dolphin swimming, wildlife viewing, heritage tours, night walks, diving and rock climbing. Tour Operators play a key role in facilitating access, promoting park values and appropriate behaviours and are key contributors to regional economies. Some undertake park management services on behalf of PV, for e.g. pest plant removal from commercial river rafts. PV also manages the Yarra River, in the centre of the city of Melbourne, including 35 commercial operators, numerous commercial and private berths and landings.

PV works with partners and lessees in the management of tourism venues. These include Queenscliff Harbour, Mount Buffalo Chalet, Mt. Dandenong Observatory, golf courses, restaurants and Brambuk, the National Park and Cultural Centre.

\subsubsection{Visitor services}

Access for nature based tourism is enabled by the provision of basic park infrastructure such as roads, safe drinking water, walking tracks, signage, campgrounds, toilets, ski lifts, car parks and picnic sites. In addition to the role of providing park infrastructure, Parks Victoria is also engaged in providing activities or destinations for visitors. This will vary from Ranger guided tours of important sites to the provision of parknotes and a website. The nature based tourism industry increasingly is able to provide not only these types of services but also a wide variety of complementary services that constitute the entire tourism experience.

It is a challenge to manage AUD1.4 billion of assets and provide the range of services and activities to visitors, to contemporary standards which include the following:

- Provision of visitor facilities and information at key tourism sites.

- Interpretation and education programs and activities at key tourism sites.

- Interpretive and self-guiding trails, Ranger interaction, tourism signage and visitor management services.

- Event management including major events such as the Australian Formula One Grand Prix and the Volvo Classic Ocean Race.

- Playing a major role in the planning and implementation of Melbourne's Commonwealth Games 2006.

\subsubsection{Marketing and promotions}

PV undertakes marketing and promotional activities, working with the tourism industry and using various tools to attract visitors to regional Victoria. These activities include: 
- Operation of a seven day a week PV Information Centre, which receives 120,000 calls a year, and a website (www.parkweb.vic.gov.au) hosting nearly a million 'visits' a year.

- Provision of park notes and publications to accredited and targeted Visitor Information Centres.

- Advertising, pictorial and editorial support of tourism publications, marketing materials and programs.

- Public relations including journalist inquiries and familiarisations, media activities, instigating and hosting travel show filming.

- Specific marketing for Healthy Parks, Healthy People campaigns (television and print) and for fee-for-entry attractions.

- Research on visitor activities, trends and impacts.

- Participation at the 'Australian Tourism Exchange' promoting park attractions to international travel trade.

- Sponsorship and participation in events including Victoria's Tourism Awards, Caravan and Camping Shows and various regional festivals and tourism conferences.

\section{Challenges for sustainable park tourism}

In managing protected areas, PV's Tourism Partnership Strategy complements Victoria's NBT Strategy 2007-2011 (in progress). The latter, is being codeveloped by three of Victoria's government agencies including Parks Victoria (Land Management), the Department of Sustainability and Environment (Policy and Land/Water Management) and Tourism Victoria (Marketing and Industry and Product Development). The NBT strategy 2007-2011 identifies four themes for Victoria - environmental sustainability, enabling private and public investment, integration of government effort, and the creation of engaging and authentic memorable experiences. These themes represent a new approach for nature based tourism in Victoria, and the pursuit of greater economic benefits (tourism yield) is emphasised, not just necessarily increased visitor numbers.

\subsection{Creation of an 'enabling environment' for investment in the NBT industry}

Despite many separate examples of positive collaboration, there has been a lack of fully integrated 'whole of Government' approach to the NBT sector, limited private investment of any scale and low investor confidence in NBT, particularly on public land. In addition there are many micro-sized lifestyle businesses with four or fewer employees, with varying levels of professionalism and expertise and high levels of business failure.

PV is participating in several projects which will create an 'enabling environment' and sustainable commercial frameworks, including:

- $\quad$ Policy and guidelines on appropriate development, acceptable and preferred public/private partnerships in natural areas and limited/ exclusive access and competitive allocation of commercial agreements. 
- Planning system provisions which define and facilitate appropriate NBT accommodation in rural and natural landscapes.

- Direct reinvestment options for PV managed tourism assets.

- Increased lease terms for NBT developments on PV estate.

- A Public Land Tour Operator and Activity Provider Licence Reform project to support stability and growth in the sector, which proposes an increase in maximum licence terms for certified tour operators on public land, from three to seven years.

- Implementation of a range of capacity building initiatives to improve existing businesses and create new opportunities.

\subsection{Natural event recovery}

Internationally, it has been shown that tourism is especially vulnerable to the often unavoidable impacts of natural and man made disasters and events, such as wars, floods and disease outbreak. The contribution of parks and related tourism activity to regional economies was recently brought into stark contrast over the past three years, following significant bushfire events in the Victoria Alps in 2003, Wilsons Promontory National Park in 2004 and in several Victorian locations including the Grampians National Park in 2006.

The fires caused severe restrictions on access to parks and reserves and a severe downturn in the regional economies. They highlighted the important role that the park estate plays in not just the protection of natural values but also in affecting the wellbeing of local communities.

In 2003, located in and around the Alpine National Park, bushfires burnt over 1 million hectares of national park and adjacent State forest. Most recently, the impacts of the 2006 fires over 6 weeks saw 160,000 hectares of public and private land burnt, and the loss of 57 houses, over 64,000 stock and four lives.

Parks Victoria has collaborated closely with the tourism industry and government in recovering from these bushfire. Dealing with the effects included reinstatement of park assets (cultural, environmental and visitor) and a contribution to the business and community recovery. PV employed local tour operators, whose businesses were closed during this time, to undertake visitor site and track assessments, in conjunction with park staff. Not only did this expedite the recovery process, it provided a badly needed income stream to businesses dependent on the park.

The reopening of sites was a process guided by safety, environment and cultural considerations. The tourism industry had the opportunity to influence the priorities for the re opening of sites.

With effective engagement and consultation between PV, the tourism industry, government and local communities, the recovery process in Victoria has progressed steadily.

\subsection{Authentic, memorable and engaging NBT products}

Authentic, memorable and engaging experiences are created from a combination of components and the links between them i.e. major infrastructure such as 
accommodation facilities, visitor interpretation centres and roads; complementary infrastructure such as walking trails, lookouts, toilets or picnic spots; self reliant or guided activities; interpretation and personal engagement with communities, land managers, and tour guides.

Holistic destination development requires crucial analysis of these gaps to satisfy the 5 A's - Access, Accommodation, Amenities, Activities and the Attraction itself [6]. The lack of one of these components will impede tourism industry growth. In Victoria, a critical gap in the 5 A's is the lack of iconic nature based accommodation, compared with its competitor destinations, as well as ageing public land infrastructure that fails to meet the needs of target markets.

The NBT strategy therefore proposes to:

- Establish through private investment three benchmark sustainable NBT accommodation projects in the Grampians, Otways and Great Ocean Road regions. These could be in park, on other public or private land.

- Upgrade critical infrastructure at Mount Buffalo Chalet in the Victorian Alps to create a more attractive private investor proposition.

- Continue to invest in the long-distance Great Ocean Walk and establish further a range of walking products that includes demountable standing camps and a high yield commercially-run walking component.

- Further establish bicycle touring attractions with supporting 'bike barn' facilities and accommodation in towns or along the tracks, with a focus in the Otways and Grampians regions.

The NBT strategy also recognises the importance of continuing to reinvigorate and invest in existing park assets and attractions, particularly those that are critical to the international perception of the state. It therefore proposes to:

- Develop visitor services, facilities, and experiences at iconic parks which allow improved visitor engagement.

- Develop a state-wide guiding brand linked to training and certification. This may include links with the Parks Victoria 'Ranger brand'.

\subsection{Sustainable destinations and 'levels of service'}

Victoria is continually endeavouring to adopt a more integrated and holistic approach to destination management and the delivery of positive, satisfying experiences. It is also committed to a significant increase in, and integration of nature based tourism marketing across government agencies.

Greater focus for industry and Government resources on identified geographic clusters, and hubs within those clusters will be undertaken. These clusters were identified based on their potential to deliver high yield NBT experiences. They were assessed based on current high levels of visitation, national parks with high 'levels of service', consumer awareness and perception, existing critical mass of NBT products, range of visitor services in hubs, and identified NBT primary product strengths from the Regional Tourism Development Plans. 
While some stakeholders within the tourism and local government sectors may have concerns with this proposal, the strategy is fundamental to sustainable nature based tourism. This approach is consistent with the state government tourism strategy, which identifies a hierarchy of destinations, and Parks Victoria's 'levels of service' framework.

In relation to infrastructure in parks and public land, the strategy proposes nature based facilities which have minimal environmental footprint and are designed carefully so as not to detract from the landscape values or conflict with the needs of other users.

In addition the following will be undertaken:

- Develop design guidelines for benchmark environmentally sustainable NBT infrastructure development.

- Implement a consistent approach for establishing and monitoring carrying capacity/impact indicators in Victoria's high use parks and execute appropriate management responses.

- Foster sustainable practices in communities through the Green Globe 21 Community Standard.

- Incorporate a regional NBT vision into the regional planning instruments of each NBT cluster.

- Develop a sustainable NBT protocol with peak conservation groups.

Traditionally there has been a distrust of the sector by some conservation groups and lobbying against commercial development and exclusivity in parks and public land. Victoria also has a strong tradition of free 'as of right' access to public land, so strategies which aim to increase yield through development of more expensive or exclusive products may also cause concern.

The previously mentioned initiatives will ensure that inappropriate NBT infrastructure development proposals lacking innovation and appropriateness to the setting will be avoided.

\section{Summary}

It has been Parks Victoria's experience that tourism and conservation can coexist and that the parties can work together in achieving shared objectives towards the goals of sustainable nature based tourism.

Parks Victoria is confident of the role it plays in park and nature based tourism and is committed to a strategy, based on partnerships and sustainability. Future directions and challenges associated with this important yet vulnerable industry will be addressed in the context of the four themes - environmental sustainability, enabling private and public investment, integration of government effort, and the creation of engaging and authentic memorable experiences.

\section{References}

[1] Tourism Victoria, Victoria's Tourism Industry Strategic Plan 2002 - 2006 (2002) 
[2] Tourism Research Australia, National and International Visitor Survey, year ending December 2005

[3] Blarney, R. and D. Hatch, Bureau of Tourism Research Occasional Paper Number 25, in Profiles and Motivations of Nature-Based Visitors to Australia, 1998, Bureau of Tourism Research: Canberra

[4] Price, Waterhouse Coopers, The Value of Parks - The Economic value of three of Victoria's national parks: Port Campbell, Grampians, Wilsons Promontory, 2003

[5] Department of Natural Resources, Economic Assessment of the Recreational values of Victorian parks (1999) (Consultancy undertaken by the former Department Natural Resources and Environment)

[6] Tourism Victoria, Parks Victoria, the Department of Sustainability and Environment, Victoria's Nature Based Tourism Strategy 2007-2011 (in progress) 